\title{
A Structural Approach on Students' Satisfaction Level with University Cafeteria
}

\author{
Mui Ling Dyana Chang ${ }^{1}$, Norazah Mohd Suki $^{2} \&$ Nalini A. ${ }^{3}$ \\ ${ }^{1}$ Centre for the Promotion of Knowledge and Language Learning, Universiti Malaysia Sabah, Malaysia \\ ${ }^{2}$ Labuan School of International Business \& Finance, Universiti Malaysia Sabah, Malaysia \\ ${ }^{3}$ School of Agribusiness and Extension, Universiti Sultan Zainal Abidin, Malaysia \\ Correspondence: Nalini A., School of Agribusiness and Extension, Universiti Sultan Zainal Abidin, Malaysia. \\ E-mail: nalini@unisza.edu.my
}

Received: July 14, 2014 Accepted: July 30, 2014 Online Published: August 22, 2014

doi:10.5539/ass.v10n18p202 URL: http://dx.doi.org/10.5539/ass.v10n18p202

\begin{abstract}
This study was carried out to identify the relationship between the food quality, price fairness, staff performance, and ambience of the university cafeteria with students' satisfaction. The survey method was employed in testing the proposed hypotheses via a structured self-administered questionnaire. This survey was conducted in Universiti Sultan Zainal Abidin (UniSZA) and a total of 93 undergraduates were selected for questioning via convenience sampling method. The results were generated by using the Structural equation modeling (SEM) technique via AMOS 21.0 computer program with maximum likelihood estimation. Based on the SEM technique, food quality and price fairness are the two most important dimensions that influence the students satisfaction on café service quality. Next, the students give less priority to staff performance and ambience. The results were differing from the previous study. The university cafeteria should take serious measurement in improving the food quality and price for long term sustainability.
\end{abstract}

Keywords: students, satisfaction, service quality, structural equation modeling, cafeteria

\section{Introduction}

The service quality and customer satisfaction are very much related to any kind of service business. These are the two most important determinants that will provide the competitive advantages in long run. The food service sector is highly fragmented with large number of small medium players such as restaurants, hotels and resorts and institutional food service (Stanton et al., 2000); whereas, the increase number of students in public and private universities in Malaysia (Dollah et al., 2012) forced university management to improve the food service at the mentioned higher learning institutions. In Malaysia, these higher learning institutions provide cafeteria which offers variety of menus and comfortable surroundings where the students experience a sense of home and where they can engage in leisurely conversation and interactive activities with their peers (Norhati \& Nurhafisah, 2013).

Most of the food service sectors, eager to improve the service quality to satisfy their existing customers and devote additional resources in capturing new ones (Noel-Levitz, 2010). The university cafeterias also need to improve and upgrade their services to maintain and chasing after new customers. Therefore, this study attempts to identify the relationship between the food quality, price fairness, staff performance and ambience of the university cafeteria especially among Universiti Sultan Zainal Abidin (UniSZA) students.

\section{Literature Review}

\subsection{Service Quality and Customer Satisfaction}

Hundreds of service quality scholars have been discussing on customer satisfactions for decades. The customer satisfaction is the heart of business marketing (Andaleeb \& Conway, 2006). Customer satisfaction is influenced not only by service quality perceptions but also by personal and situational factors and price (Aldridge \& Rowley, 1998; Patterson \& Johnson, 1993; Robinson, 1999; Rowley, 1997; Zeithaml, Bitner, \& Gremier, 2008). The customer judgment of product or service itself will provide a pleasurable level of consumption related to fulfillment (Oliver, 1997). The judgment of students in university cafeteria is important for the success of a 
cafeteria in any higher learning institution. The students' satisfaction in institutional food service sectors depends on food quality, food variety and price fairness (Xi \& Shuai, 2009). Whereas, Chang, Norazah, and Tam (2014) mentioned that the university students' satisfaction on university cafeteria depends on food quality, price fairness, staff performance and ambience.

\subsection{Food Quality}

Food quality is very much related to customer satisfaction in measuring students' satisfaction on cafeteria service level. Food quality is the quality characteristics of food that is acceptable to customer (McWilliams, 2000). The appearance of foods encompasses several basic sensory attributes such as colour, opacity, gloss, visual texture and perceived flavour (Imran, 1999). Therefore, the degree of satisfaction with university cafeteria depends mostly on the quality of meals, diversity of food, food hygiene and environment (W. G. Kim \& H. B. Kim, 2004) Hence, the following hypothesis is posited.

H1: Food quality has a positive influence on the level of student satisfaction with the university cafeteria.

\subsection{Staff Performance}

The staff performances at each food outlets are very important in increasing the level of customer satisfaction. The employees especially in service industry play vital role in the success of food service outlets. Numerous scholars explored various factors triggering a customer willingness to spread a positive electronic word-of-mouth and came to the conclusion that service quality is in fact the strongest predictor, while affecting post purchase behaviour through two altruistic mediators: expressing positive feelings and also an urge to help a restaurant company as a thank you for a great dining-out experience. The interaction between the cafeteria staff and students, such as friendly gestures (e.g. smiles and greeting and high levels of responsiveness, cleanliness and quick service) is important as it influences student satisfaction with the service quality (Barlett \& Han, 2007). The following hypothesis is hence developed:

H2: Staff performance has a positive influence on the level of student satisfaction with the university cafeteria.

\subsection{Price Fairness}

Several studies have been carried out by many scholars on price fairness or price and value. Price fairness means the judgment of whether an outcome and the process to reach an outcome are reasonable or acceptable (Bolton \& Shankar, 2003). The price to be paid for a service determines the level of quality to be demanded (Soriano, 2003). $\mathrm{He}$ also stressed that the price (value) of the meal and service are equally important when compared to other service dimensions. The recent studies by $\mathrm{Ng}$ (2005) and Xi and Shuai (2009) did consider price and value in assessing students' service quality in dining hall services. Martin-Consuegra, D., Molina, A. and Esteban, A. (2007) found that perceived price fairness positively influences customer satisfaction. The subsequent hypothesis is thus proposed:

H3: Price fairness has a positive influence on the level of student satisfaction with the university cafeteria.

\subsection{Ambience}

Bitner (1992) coined a new term servicescape with physical constituents of service environment. The servicescape consists of optimum temperature, noise, furnishings and layout combine together to influence the customer satisfaction and repeat patronage level. In addition, the design of the cafeteria environment influences the consumer's food choices and eating behaviors which call the personal food environments to promote wellness, combat obesity and complement interventions at higher levels (Raman \& Chinniah, 2011; Wansink, Painter, \& Ittersum, 2001). Furthermore, the physical setting influences customers' perceptions of service quality (Hensley \& Sulek, 2007; Norhati \& Hafisah, 2013). Hence, it is posited that:

H4: Ambience has a positive influence on the level of student satisfaction with the university cafeteria.

The suggested research framework is demonstrated in Figure 1.

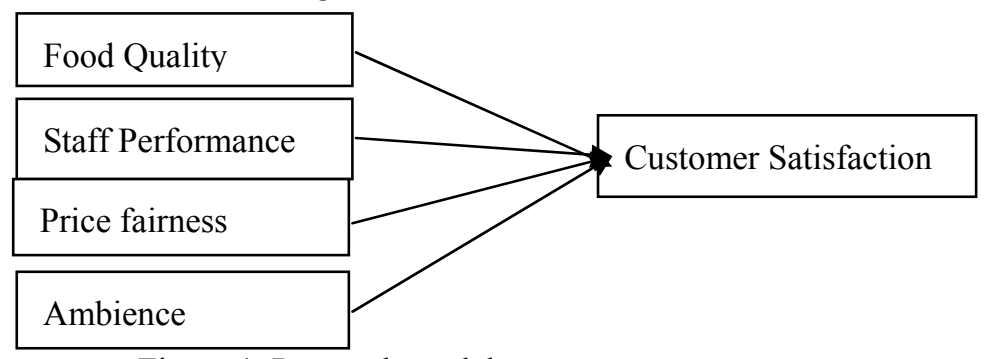

Figure 1. Research model 


\section{Methodology}

A structured self-administered questionnaire survey was successfully conducted among 93 undergraduates from Universiti Sultan Zainal Abidin (UniSZA), Malaysia via convenience sampling method. Initially, 100 questionnaires were distributed in May 2013 of which 7 were returned incomplete. The questionnaire was prepared in English and then translated into Malay by the author and reviewed by two bilingual linguists. Section A of the questionnaire contained demographic questions relating to gender, age and race, while Section B required respondents to indicate levels of agreement on factors such as food quality ( 9 items), staff performance (5 items), price fairness ( 3 items), ambience (6 items) and students' satisfaction (5 items). These variables were adapted from Kim and Kim (2004), Martin-Consuegra et al. (2007), Story, Kaphingst, Robinson-O'Brien, \& Glanz (2008); Raman and Chinniah (2011) and were measured using a 5-point Likert scale from 1 (strongly disagree) to 5 (strongly agree). Data was analyzed via Structural Equation Modeling (SEM) technique using AMOS 21.0 computer program with maximum likelihood estimation as it has the ability to ensure the consistency of the model with the data and estimate effects among constructs instantaneously.

\subsection{Data Analysis}

Table 1 details the descriptive statistics of the demographic profiles of respondents. Female respondents represented 79.6 per cent of the sample, while male respondents represented the remaining 20.4 per cent, with 17.2 per cent aged 20,20.4 per cent aged 21,22.6 per cent aged 22,15.1 per cent aged 23,12.9 per cent aged 24, 6.5 per cent aged $25,4.3$ per cent aged 26 and 1.1 per cent aged 27 . In terms of race, the majority were Malay ( 86.0 per cent), followed by Chinese ( 8.6 per cent), Indian ( 2.2 per cent), others ( 2.2 per cent) and Kadazandusun (1.1 per cent. The science and non-science streams represented about 74.2 per cent and 25.8 per cent, respectively.

Table 1. Demographic profile of respondents

\begin{tabular}{llll}
\hline & & Frequency & Percentage (\%) \\
\hline Gender & Male & 19 & 20.4 \\
Age (years olds) & Female & 74 & 79.6 \\
& 20 & 16 & 17.2 \\
& 21 & 19 & 20.4 \\
22 & 21 & 22.6 \\
& 23 & 14 & 15.1 \\
& 24 & 12 & 12.9 \\
& 25 & 6 & 6.5 \\
& 26 & 4 & 4.3 \\
Race & 27 & 1 & 1.1 \\
& Malay & 80 & 86.0 \\
& Chinese & 8 & 8.6 \\
Academic Stream & Kadazandusun & 1 & 1.1 \\
& Indian & 2 & 2.2 \\
& Others & 2 & 2.2 \\
& Science & 69 & 74.2 \\
& Non Science & 24 & 25.8 \\
\hline
\end{tabular}

\subsection{Structural Equation Modelling}

A two-step SEM approach was employed guided by maximum likelihood method of estimation: a measurement model and a structural model.

\subsection{Measurement Model}

Confirmatory factor analysis was performed to test the validity of each construct in the model, including item loading, construct reliability, and average variance extracted (AVE). Results are presented in Table 2. Each of the standardized loadings items is greater than 0.50 on their expected factor after removal of items that are not meeting the recommended value. Thus the construct validity is acceptable. The results also infer that the CR scores for all constructs exceeded the acceptable level of 0.70 , indicating a relatively high level of constructs reliability. All AVE values are greater than the cut-off value 0.50. All in all, the current data have a good convergent validity. 
Table 2. Reliability and factor loadings

\begin{tabular}{llll}
\hline & Estimate & Composite Reliability & Average Extracted Variance \\
\hline Food Quality & & 0.890 & 0.536 \\
FQ2 & 0.699 & & \\
FQ3 & 0.707 & & \\
FQ4 & 0.752 & & \\
FQ5 & 0.790 & & \\
FQ6 & 0.785 & & \\
FQ7 & 0.675 & & 0.784 \\
FQ8 & 0.710 & & \\
Price Fairness & & 0.879 & 0.606 \\
PR1 & 0.868 & & \\
PR2 & 0.902 & & 0.516 \\
Staff & & 0.754 & \\
ST3 & 0.819 & & \\
ST4 & 0.736 & & \\
Ambiance & & 0.762 & \\
AM3 & 0.729 & & \\
AM4 & 0.725 & & \\
AM6 & 0.700 & & \\
Students Satisfaction & & 0.829 & \\
S1 & 0.752 & & \\
S2 & 0.657 & & \\
S3 & 0.751 & & \\
S4 & 0.798 & & \\
\hline
\end{tabular}

Table 3. Correlation matrix

\begin{tabular}{|c|c|c|c|c|c|}
\hline & Food Quality & Price & Staff & Ambience & Students Satisfaction \\
\hline Food Quality & 0.732 & & & & \\
\hline Price Fairness & $0.533^{n \pi}$ & 0.885 & & & \\
\hline Staff & $0.345^{n \pi}$ & $0.356^{n+}$ & 0.778 & & \\
\hline Ambience & $0.480^{* \pi}$ & $0.521^{* *}$ & $0.456^{n \pi}$ & 0.718 & \\
\hline Students Satisfaction & $0.680^{* \pi}$ & $0.609^{n-*}$ & $0.318^{n *}$ & $0.596^{* \approx}$ & 0.741 \\
\hline
\end{tabular}

** Correlation is significant at the 0.01 level (2-tailed).

Table 4. Goodness-of-fit indices for structural model

\begin{tabular}{lll}
\hline Fit Indices & Accepted Value & Model Value \\
\hline Absolute Fit Measures & & \\
$\chi^{2}$ (Chi-square) & & 204.839 \\
df (Degrees of Freedom) & $<3$ & 138 \\
Chi-square/df $\left(\chi^{2} / \mathrm{df}\right)$ & $>0.9$ & 1.484 \\
GFI (Goodness of Fit Index) & $<0.10$ & 0.924 \\
RMSEA (Root Mean Square Error of Approximation) & & 0.073 \\
Incremental Fit Measures & $>0.80$ & \\
AGFI (Adjusted Goodness of Fit Index) & $>0.90$ & 0.858 \\
NFI (Normed Fit Index) & $>0.90$ & 0.978 \\
CFI (Comparative Fit Index) & $>0.90$ & 0.921 \\
IFI (Incremental Fit Index) & $>0.90$ & 0.924 \\
RFI (Relative Fit Index) & & 0.950 \\
Parsimony Fit Measures & $>0.50$ & \\
PCFI (Parsimony Comparative of Fit Index) & $>0.50$ & 0.743 \\
PNFI (Parsimony Normed Fit Index) & & 0.644 \\
\hline
\end{tabular}




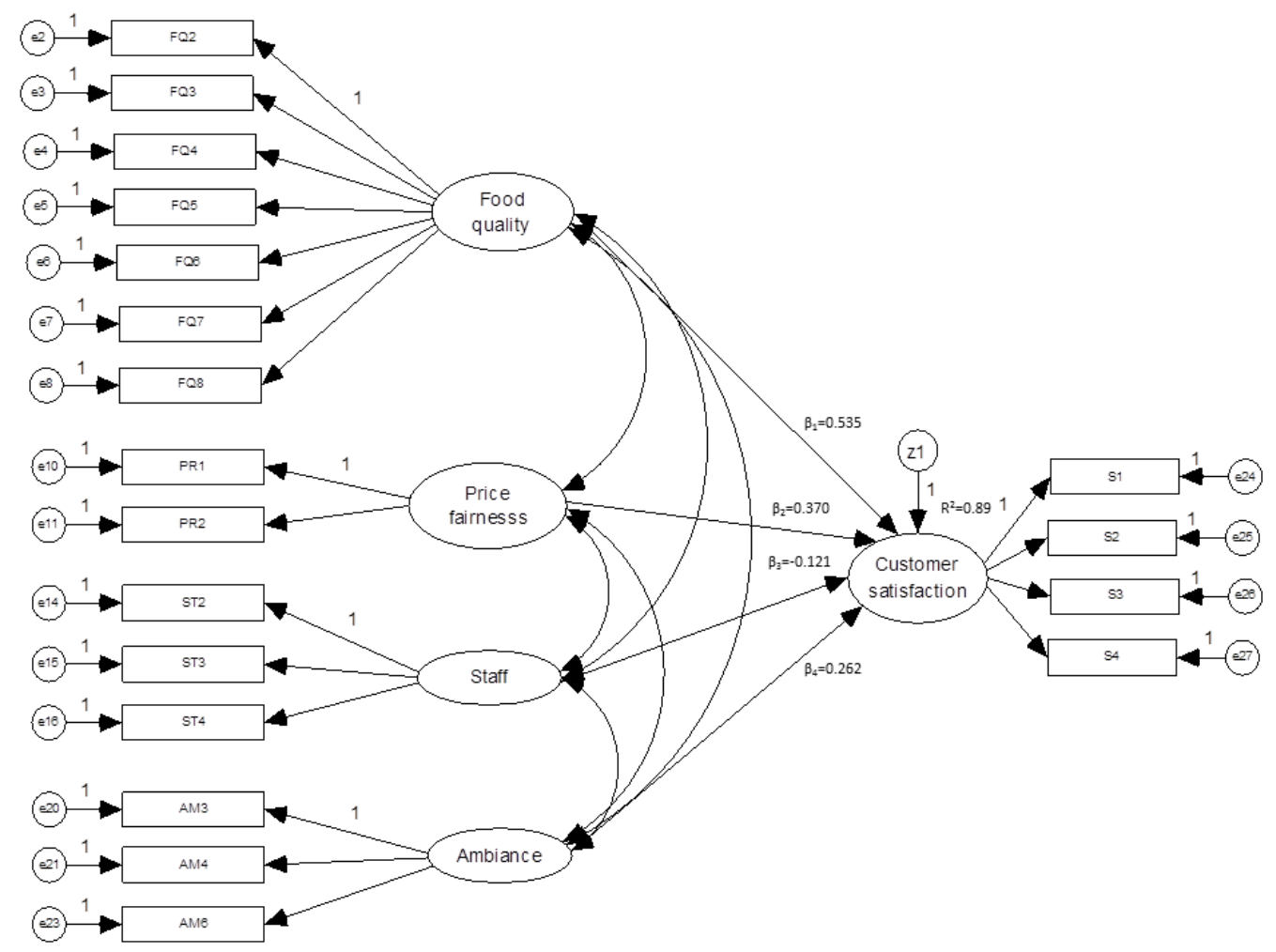

Figure 2. The result of the research model

The shared variances between factors were compared with the squared root of AVE for each construct to examine discriminant validity. The results in Table 3 shows the shared variances of the construct with other constructs were lower than the squared root of AVE of the individual factors, confirming discriminant validity. Hence, each construct was statistically different from the others.

\subsection{Structural Model}

The structural equation model was evaluated by examining fit indices and variance-explained estimates. The measure of the fit of the tested model was done through examining several goodness-of-fit indices (Table 4). The results indicated that the $\chi^{2}$ of the model was 204.839 with 138 degrees of freedom $\left(\chi^{2} / \mathrm{df}=1.484\right)$ and a root mean square error of approximation (RMSEA) of 0.063. The fit indices value for CFI, GFI, NFI, CFI, and IFI were above 0.90 and RMSEA below 0.08, indicating a satisfactory fit. The results in Figure 2 demonstrate that all independent variables accounted for $89 \%$ of the total variance in students' satisfaction $\left(\mathrm{R}^{2}=0.89\right)$. As a consequence, the results are a sign of adequate model fit between the proposed research model and the empirical data.

Table 5. Relationships with students' satisfaction on university cafeteria

\begin{tabular}{lllllll}
\hline & & & Estimate & S.E. & C.R. & $p$ \\
\hline H1. Food Quality & $\rightarrow$ & Students Satisfaction & $0.535^{*}$ & 0.171 & 3.312 & 0.000 \\
H2. Staff & $\rightarrow$ & Students Satisfaction & -0.121 & 0.084 & -1.062 & 0.288 \\
H3. Price Fairness & $\rightarrow$ & Students Satisfaction & $0.370^{*}$ & 0.092 & 2.746 & 0.006 \\
H4. Ambiance & $\rightarrow$ & Students Satisfaction & 0.262 & 0.225 & 1.331 & 0.183 \\
\hline
\end{tabular}

$* p<0.05$

The standardized parameter estimated for the structural model regarding the relationship of the independent variables (food quality, price fairness, staff and ambience) and dependent variable (students' satisfaction with university cafeteria) is summarized in Table 5. Figure 2 shows the standardized theoretical paths linking these 
variables. Hypothesis 1 posited that food quality significantly influences students' satisfaction with university cafeteria. This hypothesis was supported with a $\beta_{1}=0.535, p<0.05$. Similar significant findings appears for H3, i.e. price fairness $\left(\beta_{2}=0.370 ; p=0.006\right)$. Next, staff and ambiance both had insignificant influence on students satisfaction with university cafeteria $\left(\beta_{3}=-0.121, p=0.288 ; \beta_{4}=0.262, p=0.183\right)$, suggesting $\mathrm{H} 2$ and $\mathrm{H} 4$ are not supported.

\section{Discussion}

From the initial hypotheses of this study, the above result indicates that two hypotheses are accepted (H1 and H3) and the other two are rejected (H2 and H4). With regard to hypothesis 1, the result defined that students' satisfaction with university cafeteria is highly affected by food quality, implying H1 is significant. This finding is positively associated with those of earlier researchers (Hwang et al., 2003; W. G. Kim \& H. B. Kim, 2004; Qin \& Prybutok, 2009; Raman \& Chinniah, 2011). Food quality aspects such as careful handling, cleanliness while serving to customers, quality offered and menu variation are considered important by university students dining at the cafeteria.

Contrary, with regard to hypothesis 2 , the result explains that staff performance has no influence on the level of student satisfaction with the university cafeteria. The unsatisfactory services offered by the university cafeteria operators, staff unfriendliness, unresponsiveness (lack of smiles and greetings) slow service and unreasonable product prices contribute to this finding. The results are incompatible with preceding research (e.g. Barlett \& Han, 2007; Herrmann et al., 2007).

Furthermore, with regard to hypothesis 3, the result describes that students' satisfaction with university cafeteria is highly affected by price fairness, implying $\mathrm{H} 3$ is accepted. This is resemblance with prior findings (Herrmann et al., 2007; Martin-Consuegra et al., 2007; Oliver \& Swan, 1989), implying price fairness becomes more important to students as they acquire more information from the menus to make price comparisons and judgments whether the payment is higher or lower in relation of their expectations of the services rendered.

With the regard to the final hypothesis 4 , the result explains that ambience has no influence on the level of student satisfaction with the university cafeteria. This implies that the spatial arrangement of seating, quality of interior design, and suitability of background music do not influence students' satisfaction level with the service quality of the university cafeteria operators besides the food packaging, plate size and design, lighting and dining companions. This finding is similar with that earlier research (Hensley \& Sulek, 2007; Namkung \& Jang, 2009; Norhati \& Hafisah, 2013; Story et al., 2008).

\section{Conclusion}

The study revealed that students' satisfaction with the university cafeteria is influenced more by food quality and price fairness than staff and ambience. It is therefore important for university cafeteria operators to keep on improving the quality of food serve to the customers to maximize their satisfaction level. Furthermore, they should also offer an attractive menu at a reasonable price on the food variations and serve their customer in a proper ambience that can excite their interest in dining at the cafeteria.

This research has important implication for research and practice in the planning and designing new marketing strategies when launching new university cafeteria, depending on their target market. One of the major implications of this research is that food quality and price fairness are the important factors that the cafeteria providers should considers regardless of their target market; whether students, academicians or the public who visit and dine at the cafeteria. Remarkably, staff performance and ambience factors do not affect satisfaction of the students' with the university cafeteria. Thus, the university cafeteria should invest in these issues through staff training and development, using fresh foods in the menu choices, providing an attractive and cozy ambience and choosing furniture suitably designed at university cafeteria.

Although this study has provided useful information which may help the university cafeteria providers to improve their service quality and students' satisfaction, there are a few limitations to this research. Therefore, it is recommended that future studies expand the number of respondents and include more respondents from other age groups such as university academicians and administrative staff in order to provide more representative results and improve sample for generalizability. Since the study was carried out in Malaysia the results may not be fully generalizable for other countries, as beliefs and perceptions may differ e.g. between developed versus developing countries, and Islamic versus non-Islamic countries. This study can be further expanded using demographics, market environment, and the ideology and culture of the students as mediating and moderating variables. 


\section{References}

Aldridge, S., \& Rowley, J. (1998). Measuring customer satisfaction. Quality Assurance in Education, 4, 197-204. http://dx.doi.org/10.1108/09684889810242182

Andaleeb, S. S., \& Conway, C. (2006). Customer satisfaction in the restaurant industry: An examination of the transaction-specific model. Journal of Services Marketing, 20(1), 3-11. http://dx.doi.org/10.1108/08876040 610646536

Barlett, J. E., \& Han, F. (2007). Analysis of service quality in restaurants in China: An Eastern perspective. ABR \& TLC Conference Proceedings.

Bitner, M. J. (1992). Servicescapes: The impact of physical surroundings on customers and employees. Journal of Marketing 56, 57-71. http://dx.doi.org/10.2307/1252042

Bolton, R. N., \& Shankar, V. (2003). An empirically derived taxonomy of retailer pricing and promotion strategies. Journal of Retailing, 79(4), 213-224. http://dx.doi.org/10.1016/j.jretai.2003.09.005

Cacioppo, K. (1995). Measuring and Managing Customer Satisfaction. Harvard Business Review.

Chang, M. L., Norazah, M. D., \& Tam, Y. L. (2014). Student Satisfaction with the Service Quality: A Structural Approach. International Journal of Business, Economics and Law, 4(1), 105-111.

Dollah, S. N., Mansor, N., \& Mohamed, M. (2012). Exploring the Major Determinants of Student Satisfaction on University Cafeteria Food Services: A Malaysian Case. Interdisciplinary Journal of Research in Business, 2(7), 62-73.

Flegal, K. M., Carroll, M. D., Ogden, C. L., \& Curtin, L. R. (2010). Prevalence and trends in obesity among US adults, 1999-2008. The Journal of the American Medical Association, 303(3), 235-241. http://dx.doi.org/10. 1001/jama.2009.2014

Gilbert, G. R., \& Veloutsou, C. (2006). A cross-industry comparison of customer satisfaction. Journal of Services Marketing, 20(5), 298-308. http://dx.doi.org/10.1108/08876040610679918

Hensley, R. L., \& Sulek, J. (2007). Customer satisfaction with waits in multi-stage services. Managing Service Quality, 17(2), 152-173. http://dx.doi.org/10.1108/09604520710735173

Herrmann, A., Xia, L., Monroe, K. B., \& Huber, F. (2007). The influence of price fairness on customer satisfaction. Journal of Product \& Brand Management, 16(1), 49-58. http://dx.doi.org/10.1108/10610420 710731151

Hwang, L., Eves, A., \& Desombre, T. (2003). Gap analysis of patient meal service perceptions. International of Health Care Quality Assurance, 16(9), 143-153. http://dx.doi.org/10.1108/09526860310470874

Imram, N. (1999). The role of visual cues in consumer perception and acceptance of food products. Nutrition and Food Science, 5, 224-228. http://dx.doi.org/10.1108/00346659910277650

Kim, W. G., \& Kim, H. B. (2004). Measuring customer-based restaurant brand equity. Cornell Hotel \& Restaurant Administration Quarterly, 45(2), 115-131. http://dx.doi.org/10.1177/0010880404264507

Kivela, J., Inbakaran, R., \& Reece, J. (1999). Consumer research in the restaurant environment, part 1: A conceptual model of dining satisfaction and return patronage. International Journal of Contemporary Hospitality Management, 11(5), 205-222. http://dx.doi.org/10.1108/09596119910272739

Law, A. K. Y., Hui, Y. V., \& Zhao, X. (2004). Modeling repurchase frequency and customer satisfaction for fast food outlets. International Journal of Quality \& Reliability Management, 21(5), 545-563. http://dx.doi.org /10.1108/02656710410536563

Lengnick-Hall, C. A. (1996). Customer contributions to quality: A different view of the customer-oriented firm. Academy of Management Review, 21(3), 791-824.

Martin-Consuegra, D., Molina, A., \& Esteban, A. (2007). An integrated model of price, satisfaction and loyalty: An empirical analysis in the service sector. Journal of Product \& Brand Management, 16(7), 459-468. http://dx.doi.org/10.1108/10610420710834913

McWilliams, M. (200). Foods: Experimental Perspectives (2nd ed.). New York: Measure consumer satisfaction. Hospitality Research Journal, 17(2), 63-74.

Namkung, Y., \& Jang, S. (2008). Are highly satisfied restaurant customers really different? International Journal of Contemporary Hospitality Management, 20(2), 142-155. http://dx.doi.org/10.1108/09596110810852131 
Ng, Y. N. (2005). A study of Customer Satisfaction, Return Intention and words-of-Mouth Endorsement in University Dining Facilities. (Unpublished master's thesis). Oklahoma State University, Stillwater, Oklahoma.

Noel-Levitz. (2009). Report on Student Retention Trends. Retrieved from http://www.noellevitz.com

Norhati, I., \& Hafisah, F. N. (2013). Informal Setting for Learning on Campus: Usage and preference. Procedia-Social and Behavioral Sciences, 105(2013), 344-351.

Oliver, R. L. (1997). Satisfaction: A behavioral perspective on the consumer. New York, NY: Irwin/McGraw-Hill.

Oliver, R. L. (1999). Whence consumer loyalty. Journal of Marketing, 63, 33-44. http://dx.doi.org/10.2307/1252 099

Oliver, R. L., \& Swan, J. E. (1989). Consumer perceptions of interpersonal equity and satisfaction in transactions: A field survey approach. Journal of Marketing, 53(2), 21-35. http://dx.doi.org/10.2307/1251411

Parasuraman, A., Zeithaml, V. A., \& Berry, L. L. (1985). SERVQUAL: A multiple-item scale for measuring consumer perceptions of service quality. Journal of Retailing, 64(1), 12-40.

Patterson, P. G., \& Johnson, L. W. (1993). Disconfirmation of expectations and the gap model of service quality: An integrated paradigm. Journal of Satisfaction, Dissatisfaction and Complaining Behavior, 6(1), 90-99.

Qin, H., \& Prybutok, V. R. (2009). Service quality, customer satisfaction, and behavioral intentions in fast-food restaurants. International Journal of Quality and Service Sciences, 1(1), 78-95. http://dx.doi.org/10.1108/17 566690910945886

Raman, S., \& Chinniah, S. (2011). An investigation on higher learning students satisfaction on food service at university cafeteria. Proceedings of the 5th International Conference of Asian Academy of Applied Business. Cambodia.

Robinson, S. (1999). Measuring service quality: Current thinking and future requirements. Marketing Intelligence \& Planning, 17(1), 21-32. http://dx.doi.org/10.1108/02634509910253777

Rowley, J. (1997). Beyond service quality dimensions in higher education and towards a service contract. Quality Assurance in Education, 5(1), 7-14. http://dx.doi.org/10.1108/09684889710156530

Soriano, D. R. (2003). The Spanish Restaurant Sector: Evaluating the Perception of Quality. The Service Industries Journal, 23(2), 183-194. http://dx.doi.org/10.1080/02642060412331300952

Stanton, E., \& Sia. (2000). Malaysia HRI Food Service Sector Study. USDA and Foreign Agricultural Service. GAIN Report \# MY0017.

Story, M., Kaphingst, K. M., Robinson-O’Brien, R., \& Glanz, K. (2008). Creating Healthy Food and Eating Environments: Policy and Environmental Approaches. Annual Review of Public, 29(1), $253-272$. http://dx.doi.org/10.1146/annurev.publhealth.29.020907.090926

Wansink, B., Painter, J., \& Ittersum, K. V. (2001). Descriptive menu labels' effects on sales. Cornell Hotel and Restaurant Administration Quarterly, 42(6), 68-72.

Xi, L., \& Shuai, Z. (2009). Investigation of Customer Satisfaction in Student Food Service. An example of student cafeteria in NHH. International Journal of Quality and Service Sciences, 1(1), 113-124. http://dx.doi.org/10.1108/17566690910945903

Yildiz, S. M., \& Kara, A. (2009). The PESPERF scale: An instrument for measuring service quality in the School of Physical Education and Sports Sciences (PESS). Quality Assurance in Education, 17(4), 393-415. http://dx.doi.org/10.1108/09684880910992359

Zeithaml, V. A., Bitner, M. J., \& Gremier, D. D. (2008). Services marketing: Integrating customer focus across the Firm (5th ed.). Boston, MA: McGraw-Hill.

\section{Copyrights}

Copyright for this article is retained by the author(s), with first publication rights granted to the journal.

This is an open-access article distributed under the terms and conditions of the Creative Commons Attribution license (http://creativecommons.org/licenses/by/3.0/). 